\title{
BUSINESS PROSPECT OF THE TILAPIA HATCHERIES BY STANDARD OPERATING PROCEDURE APPLICATION OF GOOD HATCHERY PRACTICES (GHP) IN BANJAR REGENCY SOUTH KALIMANTAN
}

\author{
Fathur Rahmani \\ Master of Fisheries Science, Fisheries and Marine Faculty \\ Lambung Mangkurat University, Banjarbaru, South Kalimantan, Indonesia \\ Jl. A. Yani Km. 36 PO Box 6 Banjarbaru 70714 \\ Email: s2perikanan_unlam@yahoo.co.id
}

\begin{abstract}
This research aimed to (1) analyze the profit of the tilapia hatchery business in Banjar Regency with GHP application and comparing it with the profit before it applied GHP; and (2) to analyze the investment feasibility of the tilapia hatchery business with GHP application in Banjar Regency. This research was carried out in the Karang Intan District, Banjar Regency, South Kalimantan, with the community GHP certified hatchery units as the object. The collected data was the data that directly originated from observation results in the location of the research, and other supporting data, which related to the object of the research. The results of the research showed that by applying GHP, the tilapia hatchery business gave more profit than before applying it. By applying GHP, the tilapia hatchery business developed very profitably and feasible to be carried on. The result of investment feasibility analysis showed that the NPV was positive, the Net $B C R$ was more than 1, the IRR was more than discounted rate, and the period of the return of investment was faster than the project period.
\end{abstract}

Keywords: the tilapia hatchery businesses, GHP, investment feasibility

\section{INTRODUCTION}

Along with the growth of aquaculture business, especially the enlargement of tilapia fish, surely it must also be accompanied by the supply of seeds which satisfy the demand of tilapia fish business entrepreneurs. The seed supply generally comes from the community hatchery units in Banjar and Banjarbaru districts, as well as from government-owned hatchery units such as the Freshwater Aquaculture Center (Balai Perikanan Budidaya Air Tawar - BPBAT) Mandiangin and fish hatchery centers owned by the provincial and district/city governments. In fact, these local tilapia hatchery units tend to be overwhelmed by the demand, so that over time, the hatchery business entrepreneurs, especially the community hatchery units, are no longer paying attention to the quality of the seeds produced, but the preferred quantity in their production.

Directorate General of Aquaculture Fisheries (2013) argued so that aquaculture can take place throughout the year with maximum production, the continuity of fish seeds in both quantity and quality is required. It is also argued that the development of international issues in recent years poses multidimensional challenges that must be faced in the development of aquaculture business, one of which is the demand to carry out responsible and sustainable aquaculture.

To carry out sustainable aquaculture business activities, the application of responsible aquaculture procedures should start from the hatchery activities to the enlargement activities. In this case, in addition to sufficient quantities, the seed quality is also one of the critical determinants of successful cultivation. To produce qualified and decent seed, the hatchery business should apply seeding techniques in accordance with the standards and procedures of good hatchery, the Good Hatchery Practices (GHP).

Based on the description, the purposes of this research activity are:

1. Analyzing the profit of tilapia hatchery business that applied GHP in Banjar Regency and compares it with its profit before applying GHP.

2. Analyzing the feasibility of tilapia hatchery business investment that implements GHP in Banjar Regency.

\section{MATERIALS AND METHODS}

This research activity was carried out in the Karang Intan district, Banjar Regency, with the consideration that the community GHP 
certified hatchery units is only in the district. The data collected was the data that sourced directly from the business entrepreneurs of GHP certified tilapia fish hatchery, through interview techniques. Data analysis includes the profit analysis of tilapia fish hatchery business before and after applying GHP using the formula of business profit (Soekartrawi, 1995), and investment feasibility analysis of tilapia fish hatchery business includes Net Present Value (NPV), Net Benefit Cost Ratio (Net BCR), Internal Rate of Return (IRR) dan Payback Period analysis (Gittinger, 1982).

\section{RESULTS AND DISCUSSION}

\section{Profits of GHP Tilapia Hatchery Business}

GHP applied tilapia fish hatcheries carried out by fish farmers initially invested IDR $99,625,000$ on average, including Mandiangin brood fish strain (F2) the with the average of 30 packages (400 fishes/packs with a weight between $150-250 \mathrm{~g} / \mathrm{fish}$ ) or an average of about $2,400 \mathrm{~kg}$ with a value of IDR $84,000,000$. Optimal results can be obtained from the breeder with spawning period within three years, after three years, it can be classified as rejects and can be sold for IDR 25,000/kg. Other investment components include feed warehouse/equipment, hapa (cages), oxygen tube, strainers, fishnets, and bucket, with a total investment value of IDR 15,625,000. Based on the economic life of each investment component, the depreciation value equal to IDR $7,852,500 /$ year.

In conducting the business, the tilapia farmers enter the input of production, such as feeds, lime, fertilizers, oxygen, plastic packagings and labor, as well as fixed costs, which include ponds rental, electricity cost, and capital cost (depreciation) cost, or so-called production cost with an average of IDR 288,422,500/year.

The average production of tilapia seed is $3,000,000$ fishes/year with size $5-8 \mathrm{~cm}$, with the unit price of IDR 180/fish; it obtained the production value with the average of IDR $540,000,000 /$ year. After deducting the total average production cost of IDR $288,422,500$ /year, the average profit is IDR $251,577,500 /$ year or it can reach an average profit of IDR $20,964,800$ in a month. Details on the cost and the value of the production, as well as the profit of the tilapia hatchery business with the application of GHP, can be seen in Table 1.

The profit value is achieved after applying the standard GHP operational procedures which, when compared to the profit before applying GHP is as in Table 2.

Table 1. Cost and production value of tilapia hatchery business using GHP

\begin{tabular}{|c|c|c|c|}
\hline Description & Volume & $\begin{array}{l}\text { Unit Price } \\
\text { (IDR) }\end{array}$ & $\begin{array}{l}\text { Total } \\
\text { (IDR) }\end{array}$ \\
\hline \multicolumn{4}{|l|}{ Operational Cost } \\
\hline Feed & $15,000 \mathrm{~kg}$ & 8,500 & $127,500,000$ \\
\hline Lime & $4,500 \mathrm{~kg}$ & 1,000 & $4,500,000$ \\
\hline Fertilizer & $4,050 \mathrm{~kg}$ & 800 & $3,240,000$ \\
\hline $\mathrm{O}_{2}$ Refill & 19 times & 165,000 & $3,135,000$ \\
\hline Plastic Packaging & 19 rolls & 75,000 & $1,425,000$ \\
\hline Labor & 480 days work & 50,000 & $24,000,000$ \\
\hline \multicolumn{4}{|l|}{ Fixed Cost } \\
\hline Ponds rental & 36 unit & $4.000,0000$ & $142,000,000$ \\
\hline Electricity & 12 months & 22,500 & 270,000 \\
\hline \multirow{2}{*}{ Depreciation } & & & $3,102,500$ \\
\hline & Total & & $309,172,500$ \\
\hline \multicolumn{4}{|l|}{ Production } \\
\hline$\overline{\text { Seed }(5-8 \mathrm{~cm})}$ & 3.000.0000 fishes & 180 & $540,000,000$ \\
\hline Profit & & & $230,827,500$ \\
\hline
\end{tabular}

Source: Results of data processing (2017) 
Table 2. Comparison of tilapia hatchery business profit after and before applying GHP

\begin{tabular}{lrr}
\hline \multicolumn{1}{c}{ Description } & \multicolumn{1}{c}{ After GHP } & \multicolumn{1}{c}{ Before GHP } \\
\hline Superior broodfish & yes & no \\
Activity documentation & yes & no \\
Average production capacity/year (fish) & $3,000,000$ & $1,675,000$ \\
Seeds sale price (IDR/fish) & 180 & $150-160$ \\
Average production cost/year (IDR) & $309,172,500$ & $240,422,500$ \\
Average production value/year (IDR) & $540,000,000$ & $268,000,000$ \\
Average profit/year (IDR) & $251,557,500$ & $27,577,500$ \\
\hline
\end{tabular}

Source: Results of data processing (2017)

In the implementation of GHP in fish hatchery business, there is a necessity to use a superior broodfish and to document every business activity. As a result of the existence of these requirements, the results are very clear, especially in terms of production capacity, product selling price and allocated production cost. The production capacity of seeds produced after applying GHP is much greater than production capacity before applying GHP. Another impact is the selling price of the product also increased from the previous, which ranged from IDR 150 - 160/fish to IDR 180/fish, this is because the resulting product tends to be more uniform in size. So although in terms of production costs that before implementing GHP is smaller than that after implementing GHP, but the business profits are much larger that after applying the GHP.

Increased production capacity is possible because by using a superior broodfish, the average production of seeds produced at each spawning is at least 500 seeds with the size of $5-8 \mathrm{~cm}$ for each female broodfish, so that in five broodfish packs with 1,000 female broodfishes, they can produce at least 500,000 seeds. If each of the broodfish can be breed six times a year, the total production of seeds that can be produced averagely 3,000,000 seeds/year. The resulting seeds are entirely absorbed mostly by the floating net cages (Keramba Jaring Apung - KJA) farmers in Karang Intan and Aranio districts, Banjar Regency, and also farmers from Central Kalimantan. The farmers are already the customers and do not even want to switch to other community hatchery units (Unit Pembenihan Rakyat - UPR) even though they have to wait until the seed stock meets the ordered amount, due to the quality of the seed that is evenly distributed and lower mortality rate.

In contrast, the average seed production prior to applying the GHP was 279 fishes/broodfish, thus assuming the same number of broodfishes and breeding periods of seeds then yielded an average of 1,675,000 fishes/year. This is because the broodfish that were used comes from the local broodfish candidate marked with a clear track record of the generation. The seeds produced also tend to be less uniform and smaller so that the price is lower and based on information from tilapia KJA farmers who use the non-superior seeds, the mortality rate of the seeds can reach more than $50 \%$.

\section{Business Feasibility of Tilapia Fishing with GHP}

Based on the results of benefit analysis, preliminary information related to the projection analysis of the feasibility of tilapia fish hatchery business with the application of GHP are as follows:

1. Investment invested at the beginning of the business includes the broodfishes, feed warehouse/equipment, hapas, oxygen tube, strainers, fishnets, and bucket.

2. The ponds are calculated as rent for IDR $4,000,000 /$ pond.

3. Electricity in the form of lighting lamp allocated for IDR 20,000/month.

4. Commercial feeds at IDR $8,500 / \mathrm{kg}$.

5. Agriculture lime at IDR $1,000 / \mathrm{kg}$.

6. Manure at IDR $800 / \mathrm{kg}$.

7. Oxygen tube refill at IDR $165,000 /$ filling.

8. Plastic packaging at IDR $75,000 /$ roll.

9. Labor for IDR 50,000/days work

The feasibility test of Tilapia hatchery business in Banjar Regency is done through investment analysis by calculating Net Present Value (NPV), Net Benefit Cost Ratio (NetBCR), Internal Rate of Return (IRR) and Payback Period (PP), with $14 \%$ discount based on effective interest rate for microcredit program (Regulation of the Minister of Finance No.22/PMK.05/2010 on Second Amendment to Regulation of the Minister of Finance No.135/PMK.05/2008 concerning Credit Facility for Microcredit Program). In its calculations, the feasibility of this business is analyzed based on physical projection per year as follows: 
1. 35 units of ponds for broodfish ponds and nursery ponds.

2. 300 sacks of commercial feed @ 50 kg $(15,000 \mathrm{~kg})$.

3. $4500 \mathrm{~kg}$ of agriculture lime.

4. $4,000 \mathrm{~kg}$ of manure.

5. 20 times oxygen tube refills

6. 20 rolls plastic packaging.
7. 480 days work of labor

8. $3,000,000$ tilapia seeds $(5-8 \mathrm{~cm})$ production.

9. This tilapia hatchery business is projected for three years in accordance with the optimal period of tilapia broodfish spawning.

The feasibility projection of this hatchery business in detail can be seen in Table 3 .

Table 3. The feasibility of tilapia hatchery business with GHP

\begin{tabular}{|c|c|c|c|c|}
\hline \multirow[b]{2}{*}{ Description } & \multicolumn{4}{|c|}{ Year } \\
\hline & $\begin{array}{c}0 \\
\text { (IDR) }\end{array}$ & $\begin{array}{c}1 \\
\text { (IDR) }\end{array}$ & $\begin{array}{c}2 \\
\text { (IDR) }\end{array}$ & $\begin{array}{c}3 \\
(\text { IDR) }\end{array}$ \\
\hline \multicolumn{5}{|l|}{ Investment } \\
\hline 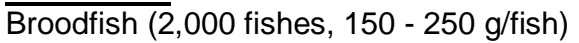 & $25,000,000$ & & & \\
\hline Feed warehouse/Equipment (1 unit) & $15,000,000$ & & & \\
\hline Hapa (2 units) & $1,500,000$ & & & \\
\hline $\mathrm{O}_{2}$ tube (1 unit) & $1,100,000$ & & & \\
\hline Strainer (3 units) & 225,000 & & & 225,000 \\
\hline Fish Net (2 units) & 120,000 & & & \\
\hline Bucket (4 units) & 180,000 & & & 180,000 \\
\hline \multicolumn{5}{|l|}{ Operational } \\
\hline Pond rental (35 units) & & $140,000,000$ & $140,000,000$ & $14,000,000$ \\
\hline Electricity (IDR 25,000/month) & & 300,000 & 300,000 & 300,000 \\
\hline Feed (15,000 kg @ IDR 8,500) & & $127,500,000$ & $127,500,000$ & $127,500,000$ \\
\hline Lime $(4,500$ kg @ IDR 1,000) & & $4,500,000$ & $4,500,000$ & $4,500,000$ \\
\hline Manure (4.000 kg @ IDR 800) & & $3,200,000$ & 3.200 .000 & $3,200,000$ \\
\hline $\mathrm{O}_{2}$ Refill $(20$ x IDR 165,000$)$ & & $3,300,000$ & $3,300,000$ & $3,300,000$ \\
\hline $\begin{array}{l}\text { Plastik Packaging (20 rolls @ IDR } \\
75.000 \text { ) }\end{array}$ & & $1,500,000$ & $1,500,000$ & $1,500,000$ \\
\hline Labor (480 days work @ IDR 50.000) & & $24,000,000$ & $24,000,000$ & $24,000,000$ \\
\hline Cash Outflow & $43,125,000$ & $304,300,000$ & $304,300,000$ & $304,705,000$ \\
\hline \multicolumn{5}{|l|}{ Income } \\
\hline$\overline{\text { Seeds } 5}$ - 8 cm @ IDR 160/fish & 0 & $480,000,000$ & $480,000,000$ & $480,000,000$ \\
\hline Broodfish reject @ IDR 25.000/kg & 0 & 0 & 0 & $66,000,000$ \\
\hline Cash Inflow & 0 & $480,000,000$ & $480,000,000$ & $546,000,000$ \\
\hline Surplus (Depisit) & $-43,125,000$ & $175,700,000$ & $175,700,000$ & $241,295,000$ \\
\hline Total Surplus & $549,570,000$ & & & \\
\hline Discount Factor (14\%) & 1.00 & 0.88 & 0.77 & 0.67 \\
\hline$N P V_{i} 14 \%$ & $-43,125,000$ & $154,122,807$ & $135,195,445$ & $162,867,252$ \\
\hline NPV & $409,060,504$ & & & \\
\hline NetBCR & 10.49 & & & \\
\hline IRR & $409 \%$ & & & \\
\hline PP (tahun) & 0.25 & & & \\
\hline
\end{tabular}

Source: Results of data processing (2017)

The feasibility analysis of the GHP applied tilapia hatchery business resulted in a positive NPV number, which means that the business is feasible to work on. This is supported by a Net $B C R$ value of more than 1 $(5,76)$, which means the business is indeed profitable, and the IRR value is $231 \%$, which is much larger than the prevailing interest rate $(14 \%)$, which means that the return on investment capital during the projection period is considered feasible as long as the interest rate is still below $409 \%$. Similarly, the value of $\mathrm{PP}$ is 0.25 ; which means that the payback period for the investment of this tilapia hatchery business is less than a year or about three months faster than the projection period (3 years), so this business is very feasible.

This projection result was obtained from the use of broodfish as much as five packets or 2,000 fishes, which consists of 1,000 male broodfishes and 1,000 female broodfishes. The projected production capacity was a minimum average production capacity of 500 seeds of 5 $8 \mathrm{~cm}$ per female. Optimally, a superior female tilapia can produce an average of 1,500 larvae in one spawning. If the mortality reaches 30 - 
$50 \%$ during breeding until the size of $5-8 \mathrm{~cm}$, then the optimal seeds that can be produced are as much as 750-1000 fishes. As for the production cost, the projected input price was the maximum input price applicable at the time of the research. For the price of seeds, the projected price was the price generally applicable in the hatchery units, which was IDR $160 /$ fish. Thus, it is very clear that by applying GHP, the tilapia business is very feasible to be carried on.

In fact, there are only two GHP certified UPR units. Several things that underlie why other UPRs are reluctant to apply GHP, among others:

1. The requirements of the GHP that require the use of a superior brood fish with clear origin information, as well as the necessity to pull out broodfishes that were used previously, causing most UPRs reluctant to do so.

2. The requirement of documentation of hatchery business activities, including standard operating procedures, forms, and records. Whereas with the documentation, information about the production process will be easily accessed and traced.

3. Biosecurity requirements such as the condition of the ponds that must be clean, the source of water that should be feasible for fish farming activities with separate construction of the input and output of water pipes and the need to not contaminate between pond plots, would be quite burdensome for most UPRs that still use the makeshift ponds construction. In this case, what is meant by biosecurity is a safeguard of the farm system from the contamination of pathogens (disease-causing organisms) from outside and prevent the development of pathogens to farm environment, covering arrangement of layout and/or construction of the ponds; setting of location access; containers, equipments and rooms sterilization, and hatchery environmental sanitation.

4. Lack of socialization or information related to the application of GHP, especially with regard to business analysis, so that the results of this study are expected to be an input material for all stakeholders, both from the government and the main actors/UPRs.

\section{CONCLUSIONS}

1. By applying GHP, tilapia hatchery business gives bigger profit compared to that achieved before applying it.
2. By applying GHP, tilapia hatchery business developed very profitably and feasible to be carried on. The result of investment feasibility analysis shows positive NPV value, with Net $B C R$ value more than 1, IRR more than discounted rate, and payback period faster than projection period.

\section{REFERENCES}

Directorate General of Aquaculture Fisheries (2013). Good Fish Hatchery Guidelines (GHP). Directorate General of Aquaculture. Jakarta.

Gittinger, J.P. (1982). Economic Analysis of Agricultural Project. John Hopkins University Press. Baltimore.

Soekartawi (1995). Farming Analysis. UI-Press. Jakarta. 